\title{
Nok nød til alle
}

Mennesker med alvorlige rusproblemer har en betydelig overhyppighet av andre sykdommer (1-3). Både somatisk og psykisk sykdom er trofaste følgesvenner i en ruskarriere. Udiagnostisert og ubehandlet kan disse føre til en tidlig død. De mindre alvorlige tilfellene kan være en hindring for optimal behandling og rehabilitering og gi pasientene store plager i dagliglivet. Personlig erfaring gjennom 15 år som fastlege for 330 pasienter med rusproblemer har lært meg at en god anamnese og et sett med supplerende undersøkelser avdekker somatisk sykdom av forskjellig alvorlighetsgrad hos de aller fleste. Det er ikke de bare de klassiske følgesvennene (hepatitter, hiv og andre infeksjoner) som dominerer, det er også sykdommer i lunger og fordøyelsessystem og smerteplager og mangeltilstander på grunn av feil eller dårlig kosthold. Elendig tannstatus er hyppig og bidrar til dårlig ernæring og dårlig selvbilde.

I sine undersøkelser av helsetilstanden hos pasienter i legemiddelassistert rehabilitering fant Ivar Skeie og medarbeidere 197 somatiske hendelser hos 35 pasienter før oppstart av behandling og en betydelig reduksjon under LAR-behandlingen (1).

Rusfeltet har fătt stor oppmerksomhet i de senere år. En av intensjonene med fastlegeordningen var å bedre allmennlegetjenestene til utsatte grupper. Tverrfaglig rus- og avhengighetsbehandling (TSB) er blitt en egen spesialisthelsetjeneste fra 2014, og de første legespesialistene i rus- og avhengighetsmedisin blir godkjent tidlig i 2015 (4).

Har den økte oppmerksomheten rundt rusproblemer og endringene i organiseringen av behandlingen av dem ført til bedre diagnostisering og behandling av de somatiske sykdommene og plagene som pasientene sliter med? Det er lite systematisk kunnskap om dette. Det er derfor nyttig at Erling Dalen og medarbeidere har undersøkt hvorledes det står til med den somatiske helsen til pasientene ved en ruspoliklinikk (5). Artikkelen i dette nummer av Tidsskriftet tyder på at det er langt igjen før vi kan si oss tilfreds med tingenes tilstand på dette feltet. En grundig kartlegging av den somatiske helsetilstanden hos 155 pasienter ved poliklinikken avdekket til sammen 769 diagnoser. Sannsynligvis kunne det vært enda flere, fordi man ikke har gjort spirometri under den kliniske kartleggingen, noe som burde vært obligatorisk i en pasientpopulasjon med $83 \%$ dagligbrukere av nikotin. Det er heller ikke undersøkt kjønnshormoner og D-vitaminstatus. Kun fire av pasientene ble funnet å være helt somatisk friske. De aller fleste av de tilstandene som ble funnet, lar seg diagnostisere i allmennpraksis, og flertallet av pasientene kan også behandles her. Manglende somatiske helseopplysninger i henvisningene kan tyde på at dette tradisjonelt ikke har vært tema ved denne ruspoliklinikken. Men når forfatterne finner at tilfredsstillende opplysninger om somatisk helsetilstand fortsatt manglet hos $61 \%$ av pasientene etter en purrerunde, kan dette tyde på at fastlegene ikke har kartlagt dette før henvisning.

Artikkelen gir grunnlag for mange refleksjoner. For det første er det tankevekkende at man på den aktuelle ruspoliklinikken først nå har gjort en grundig kartlegging av pasientenes helsetilstand. Det er å håpe at man ved andre institusjoner og poliklinikker innen tverrfaglig rus- og avhengighetsbehandling allerede har rutiner for systematisk undersøkelse av den somatiske helsetilstanden hos sine pasienter. For det andre tyder dette materialet på at fastlegene i for liten grad har gjort dette. Min erfaring samsvarer med det jeg synes jeg kan lese ut av artikkelen, nemlig at tingenes tilstand ikke er ideell. Hva kan gjøres for å bedre situasjonen?
Kunnskap og holdninger er viktige stikkord. Et helsevesen preget av moralisme og avvisning vil vanskelig kunne gi god medisinsk hjelp for somatiske sykdommer og plager. I forslaget til retningslinjer for rusbehandling anbefales somatisk utredning, vurdering av behovet for tannbehandling og vurdering av ernæringsstatus tidlig i behandlingsforløpet (6). I allmennpraksis bør man gjøre en systematisk kartlegging av somatiske sykdommer og plager ved første gangs konsultasjon.

Pasienter med ruslidelser er opptatt av sin helse, og en grundig somatisk undersøkelse oppfattes som god omsorg og kan gi grunnlag for et godt samarbeid rundt selve rusproblemet senere. Noen av de mest lidende pasientene er ustabile og har problemer med å møte opp til avtalt time, og de har liten betalingsevne og -vilje. Et lite skritt for å legge til rette for en likeverdig behandling av ruspasienter hos allmennlegen er å innføre forhåndsbetalt frikort for denne gruppen. Det går også an å mobilisere feltsykepleien eller sosialfaglige oppfølgere til å hjelpe pasienten til fastlegen.

De pasientene som henvises til spesialisthelsetjenesten, bør være godt utredet for somatiske sykdommer og plager hos sin fastlege. Men spesialisthelsetjenesten kan ikke ta for gitt at dette er gjort. Ved innleggelse eller oppstart av poliklinisk behandling i institusjoner for tverrfaglig rus- og avhengighetsbehandling må det derfor gjøres en vurdering og kartlegging av somatiske plager og sykdommer, og nødvendige supplerende undersøkelser og eventuelt behandling bør iverksettes.

Ansvaret for at pasienter med alvorlige rusproblemer blir kartlagt og får god behandling for sine somatiske sykdommer og plager ligger hos både primærlegen og spesialisten. Derfor gjelder overskriften Det er nød nok til alle for alle involverte. Begge nivåer må ta på seg ansvaret for diagnostisering og behandling av disse pasientene.

\section{Dagfinn Haarr}

dhaarr@online.no

Dagfinn Haarr (f. 1952) er spesialist i samfunnsmedisin og i allmenn-

medisin. Han er kommuneoverlege i Kristiansand.

Forfatter har fylt ut ICMJE-skjemaet og oppgir ingen interessekonflikter.

\section{Litteratur}

1. Skeie I, Brekke M, Lindbaek M et al. Somatic health among heroin addicts before and during opioid maintenance treatment: a retrospective cohort study. BMC Public Health 2008; 8: 43.

2. Nasjonal retningslinje for legemiddelassistert rehabilitering ved opioidavhengighet. Oslo: Helsedirektoratet, 2010.

3. Heroin: abuse and addiction. Rev. utg. NIDA Research Report Series. Bethesda, MD: National Institute on Drug Abuse, 2005.

4. Stoltenberg-utvalget. Rapport om narkotika. www.regjeringen.no/nb/dep/hod/ dok/rapporter_planer/rapporter/2010/Stoltenberg-utvalget-Rapport-omnarkotika.html?id=608661 (5.1.2015).

5. Dalen E, Holmen J, Nordahl HM. Somatisk helse hos pasienter ved en ruspoliklinikk. Tidsskr Nor Legeforen 2015; 135: 127-31.

6. Nasjonal retningslinje for behandling og rehabilitering av rusmiddelproblemer og avhengighet. Høringsutkast. Oslo: Helsedirektoratet, 2014. 